\title{
Efektivitas Pengelolaan Dana Bantuan Operasional Sekolah (BOS) Dalam Meningkatkan Sarana Dan Prasarana Pendidikan (Studi di SDN 44 Mande Kota Bima)
}

\author{
Rahmad Hidayat', M. Rahmatul Burhan², Al Ma'ruf ${ }^{3}$ \\ ${ }^{1}$ Prodi Administrasi Publik, Universitas Muhammadiyah Mataram, Indonesia \\ ${ }^{2}$ Prodi Administrasi Publik, Universitas Muhammadiyah Mataram, Indonesia \\ ${ }^{3}$ Prodi Administrasi Publik, Universitas Muhammadiyah Mataram, Indonesia
}

\section{INFO ARTIKEL}

\section{Riwayat Artikel:}

Diterima: 08-08-2019

Disetujui: 25-09-2019

\section{Kata Kunci:}

1. Efektivitas

2. Pengeloaan

3. Dana Bantuan

4. SDN 44 Mande

5. Kota Bima

\section{ABSTRAK}

Abstrak: Bantuan Operasional Sekolah (BOS) adalah program pemerintah yang pada dasarnya untuk penyediaan pendanaan biaya operasi nonpersonalia bagi satuan pendidikan, dengan sasaran semua sekolah SD/SDLB dan SMP/SMPLB/SMPT, termasuk SD-SMP Satu Atap (SATAP) dan Tempat Kegiatan Belajar Mandiri (TKB Mandiri) yang diselenggarakan oleh masyarakat, baik negeri maupun swasta di seluruh provinsi di Indonesia, dana BOS dikeluarkan dalam empat triwulan untuk satu tahun (satu periode), berdasarkan prosedur yang ada dana BOS perlu di kelola secara relevan dan efektif. Dalam pelaksanaan dana BOS, ini dibagi menjadi 8 standar penggunaan atau aliran dana BOS yaitu: Pengembangan Kompetensi Kelulusan, Pengembangan Standar Isi, Pengembangan Standar Proses, Pengembangan Pendidikdan Tenaga Kependidikan, Pengembangan Sarana dan Prasarana Sekolah, Pengembangan Standar Pengelolaan, Pengembangan Standar Pembiayaan, Pengembangan dan Implementasi Sistem Penilaian.

Jenis penelitian ini menggunakan jenis deskriptif kualitatif. Lokasi penelitian ini dilaksanakan di SDN 44 Mande Kota Bima, Kelurahan Mande, Kecamatan Mpunda, Kota Bima. Sumber data dalam penelitian ini terdiri dari dua yaitu: (a) Data primer atau data utama, dan (b) Data sekunder atau data pendukung.

Berdasarkan hasil penelitian dan pembahasan maka penelitian ini dapat disimpulkan sebagai berikut: (1) SDN 44 Mande Kota Bima dalam pengelolaan dana bantuan operasional sekolah (BOS) telah berjalan sesuai dengan petunjuk teknis pengelolaan dana bantuan operasional sekolah (JUKNIS BOS), (2) Faktor Pendukung, Adapun factor pendukung dalam pengelolaan dana bantuan operasional sekolah (BOS) adalah sebagai berikut: (a) Dukungan Pemerintah dengan memberikan petunjuk teknis pengelolaan dana BOS dan sosialisasi tentang tata cara pengelolaan dana bantuan operasional sekolah dari Dinas Pendidikan, (b) Terjalinnya bentuk kerjasama yang baik dari pihak pengelola dana BOS, Komite Sekolah dan para Guru, Pemerintah (Dinas Pendidikan dan Kebudayaan Kota bima), (c) Motivasi yang tinggi dan kinerja yang maksimal untuk mengembangkan kualitas pendidikan, (d) Dukungan dari para guru baik dengan sumbangan pemikiran maupun dengan dukungan tenaga. Sedangkan, Faktor penghambat, Adapun factor penghambat dalam pengelolaan dana bantuan operasional sekolah (BOS) yaitu: (a) Waktu pencairan dana sering mengalami keterlambatan, (b) Anggaran yang diperoleh tidak sebanding dengan kebutuhan sekolah, (c) Sekolah dibatasi dalam melakukan perbaikan berat sehingga sekolah masih mengalami kekurangan ruangan, 
Keyword:

1. effectiveness

2. Management

3. Donation

4. SDN 44

5. Bima City dan (d) Dana bantuan operasional sekolah belum mampu membiayai seluruh program sekolah secara merata/menyeluruh.

\section{Abstract}

School Operational Assistance (BOS) is a government program that is basically to provide funding for non-personnel operating costs for education units, targeting all SD / SDLB and SMP / SMPLB / SMPT schools, including One-Roof SD-SMP (SATAP) and Independent Learning Activities Sites (TKB Mandiri) organized by the public, both public and private in all provinces in Indonesia, BOS funds are issued in four quarters for one year (one period), based on existing procedures BOS funds need to be managed in a relevant and effective way. In the implementation of BOS funds, this is divided into 8 standards for the use or flow of BOS funds, namely: Development of Graduation Competencies, Development of Content Standards, Development of Process Standards, Development of Teachers and Education Personnel, Development of School Facilities and Infrastructure, Development of Management Standards, Development of Funding Standards, Development and Implementation of Assessment Systems This type of research uses a descriptive type of quality atif. The location of this study was conducted at SDN 44 Mande Kota Bima, Mande Village, Mpunda District, Bima City. data sources in this study consisted of two, namely: (a) Primary data or primary data, and (b) secondary data or supporting data. Based on the results of research and discussion, this study can be concluded as follows: (1) SDN 44 MandeBima City in the management of school operational assistance funds (BOS) has run according to the technical guidelines for managing school operational assistance funds (JUKNIS BOS), (2) Supporting Factors, The supporting factors in managing school operational assistance funds (BOS) are as follows: (a) Support The government by providing technical guidelines on the management of BOS funds and dissemination of procedures for managing school operational assistance funds from the Education Office, (b) Establishing good forms of cooperation from the BOS fund managers, School Committees and Teachers, Government (Education and Culture Office of the City of Bima ), (c) High motivation and maximum performance to develop the quality of education, (d) Support from pa The teacher is good with the contribution of thought and with the support of staff. Meanwhile, the inhibiting factors, the inhibiting factors in the management of school operational assistance funds (BOS), namely: (a) Time of disbursement of funds often experience delays, (b) The budget obtained is not proportional to the needs of the school, (c) Schools are limited in making heavy repairs so that schools still lack space, and (d) School operational assistance funds have not been able to fund all school programs equally / thoroughly.

\section{Latar Belakang}

Pendidikan merupakan salah satu aspek penting dalam pembangunan suatu daerah, karena pendidikan sebagai pencipta SDM yang berkualitas memiliki kontribusi sangat besar terhadap suatu kemajuan. Sekolah sebagai satuan lembaga pendidikan, yang melaksanakan sistem belajar mengajar didalamnya terdiri dari tiga tahap yaitu:
(1) input, suatu keadaan siswa yang belum memiliki pengetahuan dan keterampilan khusus, (2) transformasi, merupakan hal yang paling penting dalam pendidikan dimana terjadi proses Kegiatan Belajar Mengajar (KBM), pada tahap ini terjadi proses pembinaan dan bimbingan terhadap siswa agar memiliki keterampilan atau pengetahuan khusus, dan (3) output merupakan hasil dari proses yang di harapkan. Jika proses KBM berjalan sesuai 
dengan rancangan maka akan menghasilkan output yang berkualitas, berupa tenaga kerja. Pemerintah berkewajiban meningkatkan pendidikan melalui kebijakan-kebijakan yang menuntut peningkatan mutu pendidikan.Rancangan visi dan misi harus relevan disesuaikan dengan perkembangan zaman yang ada serta dengan jenjangan atau tahapan pendidikan formal, muali dari Sekolah Dasar (SD) sampai Perguruan Tinggi (PT).

Bagi suatu bangsa yang ingin maju, pendidikan harus dipandang sebagai sebuah kebutuhan sama halnya dengan kebutuhankebutuhan lainnya. Maka tentunya peningkatan mutu pendidikan juga berpengaruh terhadap perkembangan suatu bangsa.Ibrahim (2012) menyatakan, sekolah dasar adalah bagian dari pendidikan dasar yang menyelengarakan pendidikan enam tahun.Sekolah dasar merupakan satuan pendidikan yang paling penting keberadaannya. Menurut Peraturan Pemerintah Nomor 17 Tahun 2010 Tentang Pengelolaan dan Penyelengaraan Pendidikan bahwa, tanpa menyelesaikan pendidikan pada sekolah dasar atau yang sederajat, secara formal seseorang tidak mungkin dapat mengikuti pendidikan di Sekolah Lanjutan Tingkat Pertama (SLTP). Untuk itu pendidikan dasar bertujuan memberikan bekal kemampuan dasar kepada siswa untuk mengembangkan kehidupannya sebagai pribadi, anggota masyarakat, warga negara, dan anggota umat manusia serta menyiapkan siswa untuk mengikuti pendidikan menengah.Memperhatikan peranannya yang demikian besar itu. Sekolah dasar harus dipersiapkan dengan sebaik-baiknya secara sosial institusional maupun fungsional-akademik, baik secara sosial-institusional berarti sekolah dasar harus disiapkan dengan sebaik-baiknya agar berfungsi sebagai tempat terjadinya proses sosialisasi antar anak didik yang pada akhirnya membina dan mengantarkan anak didik kearah kedewasaan secara mental maupun sosial, sedangkan secara fungsional-akademis berarti seluruh perangkat sekolah dasar, seperti tenaga, kurikulum, dan perangkat pendidikan lainya harus dipersiapkan untuk mengemban pendidikan.

Sesuai dengan Undang-Undang Nomor 20 Tahun 2003 tentang sistem pendidikan nasional, bahwa setiap warga negara yang berusia 7-15 tahun wajib mengikuti pendidikan dasar. Pasal 34 ayat 2 menyebutkan bahwa, pemerintah pusat dan pemerintah daerah menjamin terselenggaranya wajib belajar minimal pada jenjang pendidikan dasar tanpa memungut biaya, serta pada ayat 3 menyatakan bahwa pendidikan merupakan tanggungjawab negara yang diselengarakan oleh lembaga pendidikan (sekolah). Konsekuensi dari amanat undang-undang tersebut adalah pemerintah dan pemerintah daerah wajib memberikan layanan pendidikan bagi seluruh peserta didik pada tingkat pendidikan dasar (SD dan SMP) serta satuan pendidikan lain yang sederajat.

Pendidikan merupakan salah satu kunci penanggulangan kemiskinan dalam jangka menengah dan jangka panjang. Namun, sampai dengan saat ini masih banyak orang miskin yang memiliki keterbatasan akses untuk memperoleh pendidikan bermutu, hal ini disebabkan antara lain karena mahalnya biaya pendidikan. Disisi lain, Undang-Undang Nomor 20 Tahun 2003 tentang Sistem Pendidikan Nasional mengamanatkan bahwa setiap warga negara berusia 7-15 tahun wajib mengikuti pendidikan dasar, yang dikenal dengan Program Wajib Belajar Pendidikan Dasar Sembilan Tahun. Konsekuensi dari hal tersebut maka pemerintah wajib memberikan layanan pendidikan bagi seluruh peserta didik pada tingkat pendidikan dasar (SD/MI dan SMP/Mts serta satuan pendidikan yang sederajat).

Dalam perkembangan dunia pendidikan dewasa ini dengan mudah dapat dikatakan bahwa masalah pembiayaan menjadi masalah yang cukup pelik untuk dipikirkan oleh para pengelola pendidikan. Karena masalah pembiayaan pendidikan akan menyangkut masalah tenaga pendidik, proses pembelajaran, sarana prasarana, pemasaran dan aspek lain yang terkait dengan masalah keuangan. Fungsi pembiayaan tidak mungkin dipisahkan dari fungsi lainnya dalam pengelolaan sekolah. Oleh karena itu dapat dikatakan bahwa pembiayaan menjadi masalah sentral dalam pengelolaan kegiatan pendidikan. Ketidakmampuan suatu lembaga untuk menyediakan biaya, akan menghambat proses belajar mengajar. Hambatan pada proses belajar mengajar dengan sendirinya menghilangkan kepercayaan masyarakat pada suatu lembaga. Namun bukan berarti bahwa apabila tersedia biaya yang berlebihan akan menjamin bahwa pengelolaan sekolah akan lebih baik. Hal tersebut dapat menghambat upaya penuntasan Program Wajib Belajar Pendidikan Dasar Sembilan Tahun, karena penduduk miskin akan semakin sulit memenuhi kebutuhan biaya pendidikan.Meningkatnya kebutuhan dalam pendidikan, mendorong pemerintah Indonesiamenyalurkan berbagai bantuan demi kelangsungan pendidikan di Indonesia, salahsatunya adalah dana Bantuan Operasional Sekolah (BOS). Dana bantuan operasionalSekolah 
(BOS) diperuntukkan bagi setiap sekolah tingkat dasar di Indonesia dengantujuan meningkatkan kualitas pendidikan demi tuntasnya wajib belajar Sembilan tahun yang bermutu.

Seperti yang dikutip dari laman resmi CNN Indonesia, Direktur Jenderal Pendidikan Dasar dan Menengah Kementerian Pendidikan dan Kebudayaan Hamid Muhammad menyatakan penyimpangan anggaran Dana Alokasi Khusus atau Biaya Operasional Sekolah (BOS) disebabkan oleh adanya pelanggaran regulasi. Pelanggaran ini dilakukan oleh beberapa Pemerintah Daerah dan sekolah penerima dana. Dia menambahkan, pelanggaran ini mengakibatkan proses penyaluran dana BOS tidak efektif dan timbulnya indikasi korupsi. "Penyimpangan di lapangan itu (terjadi) karena tidak mengikuti ketentuan regulasi yang diberikan oleh Kementerian.Aturan banyak yang ditabrak, akhirnya munculah masalah,".

Lebih lanjut, ia mengklaim, Kemedikbud berencana untuk mengevaluasi regulasi terkait dengan penyaluruan dana BOS. Namun, ia enggan menyampaikan regulasi apa yang menjadi penyebab penyaluran dana BOS bermasalah. "Nanti kita evaluasi lagi regulasinya.Apa yang menyebabkan mereka (daerah penerima BOS) itu menyimpang.Yang paling banyak kenapa menyimpang karena regulasi ditabrak" ujar Hamid. Berdasarkan pantauan ICW, sejak tahun 2005-2018 terdapat sekitar 425 kasus korupsi dalam sektor pendidikan dengan kerugian negara mencapai Rp. 1,3 triliun dan nilai suap mencapai Rp. 55 miliar. Dari data ini terungkap bahwa objek yang paling banyak dikorupsi ialah DAK.Sekitar 85 kasus korupsi pada sektor pendidikan berasal dari penyelewengan pengelolaan DAK dengan kerugian mencapai Rp. 377 miliar.

Kebijakan Dana BOS bukan berarti berhentinya permasalahan pendidikan, masalah baru muncul terkaitketidakefektifan pengelolan dana BOS, tujuan dari pemerintah sendiri baik, namun terkadang sistem yang ada menjadi bumerang dan menghadirkan masalah baru, selain itu pribadi dan budaya manusia Indonesia ikut berpengaruh terhadap penyelewengan dan ketidakefektifan pengelolaan dana BOS. Oleh karena itu dibutuhkan kerja sama semua elemen dalam mewujudkan efektifitas pengelolaan dana BOS.

\section{Tinjauan Pustaka}

\section{a. Implementasi Kebijakan}

Dalam setiap implementasi sebuah kebijakan selalu dipengaruhi oleh hal-hal yang dapat menyebabkan berhasil atau tidaknya sebuah implementasi kebijakan. Dalam buku yang berjudul
Policy Implementation and Bureaucracy, Randall B. Ripley dan Grace A. Franklin menuliskan tentang 2 pendekatan untuk menilai implementasi kebijakan, yang menyatakan:

"Ada dua prinsip dalam menilai implementasi.Satu pendekatan berfokus pada kepatuhan.Ia bertanya apakah pelaksana mematuhi prosedur yang ditentukan, jadwal, dan batasan. Perspektif kepatuhan menetapkan model yang sudah ada sebelumnya tentang perilaku implementasi yang benar dan mengukur perilaku aktual yang menentangnya.Pendekatan kedua untuk menilai implementasi adalah dengan menanyakan bagaimana implementasi berjalan.Apa yang diraihnya? Mengapa?Perspektif ini dapat dikategorikan sebagai induktif atau empiris. Kurang elegan, pertanyaan utama adalah apa yang terjadi? dan mengapa?...'(Ripley dan Franklin, 1986:11)

Dari uraian tersebut, implementasi sebuah kebijakan menurut Ripley dan Franklin di lihat dari: 1. Kepatuhan

Tingkat keberhasilan implementasi kebijakan dapat di ukur dengan melihat tingkat kepatuhan (baik tingkat kepatuhan bawahan kepada atasan, atau kepatuhan implementor terhadap peraturan) dalam mengimplementasikan sebuah program.Kepatuhan tersebut mengacu pada perilaku implementor itu sendiri sesuai dengan standar dan prosedur serta aturan yang ditetapkan oleh kebijakan. Implementasi kebijakan akan berhasil apabila para implementornya mematuhi aturanaturan yang diberikan. Berdasarkan hal tersebut terdapat 2 indikator dalam pendekatan kepatuhan:

a. Perilaku Implementor

b. Pemahaman Implementor terhadap Kebijakan

Pendekatan ini melihat bagaimana implementasi berlangsung serta untuk melihat faktor-faktor penyebab yang mempengaruhi suatu program.Ripley dan Franklin menjelaskan ada 5 indikator dalam menjelaskan pendekatan ini. Seperti yang terdapat dalam buku Policy Implementation and Bureaucracy:

"...lima fitur yang paling penting yang dibahas dalam kelanjutan bab ini yaitu: banyaknya aktor yang terlibat, kejelasan tujuan, kompleksitas program pemerintah, partisipasi unit pemerintahan di semua tingkat wilayah, dan faktor-faktor yang mempengaruhi implementasi"

2. Banyaknya Aktor yang Terlibat

Proses implementasi melibatkan banyak aktor. Dengan kata lain, semakin kompleks suatu program yang dijalankan oleh pemerintah, maka semakin banyak aktor yang terlibat. Pelaksana kebijakan harus memiliki keterampilan yang 
diperlukan untuk melaksanakan pekerjaan. Kurangnya personil yang terlatih dengan baik akan menghambat pelaksanaan kebijakan.Ada beberapa hal yang menjelaskan lebih lanjut mengenai indikator ini:

a. Number and Identity (Jumlah dan Identitas).

b. The Role of Interest Group (Peran dari Pihak yang Berkepentingan).

c. Lock of Hierarchy (Ketiadaan Hirarki).

3. Kejelasan Tujuan

Kejelasan dan konsistensi tujuan dapat dipahami sebagai kejelasan isi kebijakan. Semakin jelas dan rinci isi sebuah kebijakan, maka kebijakan tersebut akan mudah diimplementasikan karena implementor mudah memahami dan menerjemahkan dalam tindakan nyata, sebaliknya ketidakjelasan isi kebijakan merupakan potensi lahirnya distorsi dalam implementasi kebijakan.

4. Perkembangan dan Kerumitan Program

Kerumitan program dilihat dari tingkat kerumitan aturan program yang bersangkutan. Dinamisnya petunjuk pelaksanaan yang dibuat akan mempengaruhi berhasil atau tidaknya program diimplementasikan.

1. Partisipasi pada Semua Unit Pemerintahan

Partisipasi pada semua unit pemerintahan yang dimaksud adalah partisipasi dari semua aktor yang terlibat dalam implementasi program tersebut

2. Faktor-faktor yang Tidak Terkendali yang Mempengaruhi Implementasi

Faktor yang tidak terkendali ini yaitu apakah ada faktor-faktor di luar teknis (yang telah melampaui batas kontrol dari implementor) yang secara tidak langsung berhubungan dengan pengimplementasian program, sehingga dapat menghambat, bahkan menggagalkan implementasi program yang telah dirancang sebelumnya.

\section{b. Konsep Efektivitas}

Kurniawan menjelaskan jika efektivitas merupakan kemampuan melaksanakan tugas, fungsi (operasi kegiatan program atau misi) dari pada suatu organisasi atau sejenisnya yang tidak adanya tekanan atau ketegangan diantara pelaksanaannya.Pengertian tersebut mengartikan bahwa efektivitas merupakan tahap dicapainya keberhasilan dalam mencapai tujuan yang telah ditetapkan.Efektivitas selalu terkait dengan hubungan antara hasil yang diharapkan dengan hasil yang sesungguhnya dicapai.Berbeda dengan pendapat Susanto, yang memberikan definisi tentang Efektivitas merupakan daya pesan untuk mempengaruhi atau tingkat kemampuan pesanpesan untuk mempengaruhi. Jadi dapat diartikan jika efektifitas sebagai suatu pengukuran akan tercapainya tujuan yang telah direncanakan sebelumnya secara matang.

Effendy menjelaskan efektivitas adalah komunikasi yang prosesnya mencapai tujuan yang direncanakan sesuai dengan biaya yang dianggarkan, waktu yang ditetapkan dan jumlah personil yang ditentukan. Jadi dapat diartikan bahwa indikator efektivitas dalam arti tercapainya sasaran atau tujuan yang telah ditentukan sebelumnya merupakan sebuah pengukuran dimana suatu target telah tercapai sesuai dengan apa yang telah direncanakan.

\section{c. Ukuran Efektivitas}

Mengukur efektivitas organisasi bukanlah hal yang sangat sederhana, karena efektivitas dapat dikaji dari berbagai sudut pandang dan tergantung pada siapa yang menilai serta menginterpretasikannya. Bila dipandang dari sudut produktivitas, maka seorang manajer produksi memberikan pemahaman bahwa efektivitas berarti kualitas dan kuantitas (output) barang dan jasa.

Pengukuran efektivitas dapat dilakukan dengan melihat hasil kerja yang dicapai oleh suatu organisasi.Efektivitas dapat diukur melalui berhasil tidaknya suatu organisasi mencapai tujuantujuannya.Apabila suatu organisasi berhasil mencapai tujuan, maka organisasi tersebut dapat dikatakan telah berjalan dengan efektif.Hal terpenting adalah efektifitas tidak menyatakan tentang berapa besar biaya yang dikeluarkan untuk mencapai tujuan tersebut. Efektivitas hanya melihat apakah proses program atau kegiatan tersebut telah mencapai tujuan yang telah ditetapkan.

Untuk itu perlu diketahui alat ukur efektivitas kinerja, menurut Richard dan M. Steers yang meliputi :

1) Kemampuan Menyesuaikan Diri

Kemampuan manusia terbatas dalam segala hal, sehingga dengan keterbatasannya itu menyebabkan manusia tidak dapat mencapai pemenuhan kebutuhannya tanpa melalui kerjasama dengan orang lain. Kunci keberhasilan organisasi adalah kerjasama dalam pencapaian tujuan.Setiap orang yang masuk dalam organisasi dituntut untuk dapat menyesuaikan diri dengan orang yang bekerja di dalam organisasi tersebut maupun dengan pekerjaan dalam organisasi tersebut.

2) Prestasi Kerja

Prestasi kerja adalah suatu hasil kerja yang dicapai seseorang dalam melaksanakan tugas-tugas yang dibebankan kepada seseorang yang didasarkan atas kecakapan, pengalaman, kesungguhan dan waktu.Dari pendapat tersebut dapat disimpulkan bahwa dengan kecakapan, pengalaman, 
kesungguhan dan waktu yang dimiliki oleh seorang pegawai maka tugas yang diberikan dapat dilaksanakan sesuai dengan tanggung jawab yang dibebankan kepadanya.

3) Kepuasan Kerja

Kepuasan kerja yang dimaksud adalah tingkat kesenangan yang dirasakan seseorang atas peranan atau pekerjaannya dalam organisasi.Tingkat rasa puas individu bahwa mereka mendapat imbalan yang setimpal, dari bermacammacam aspek situasi pekerjaan dan organisasi tempat mereka berada.

4) Kualitas

Kualitas dari jasa atau produk primer yang dihasilkan oleh organisasi menentukan efektivitas kinerja dari organisasi itu.Kualitas mungkin mempunyai banyak bentuk operasional, terutama ditentukan oleh jenis produk atau jasa yang dihasilkan oleh organisasi tersebut.

5) Penilaian Oleh Pihak Luar

Penilaian mengenai organisasi atau unit organisasi diberikan oleh mereka (individu atau organisasi) dalam lingkungan organisasi itu sendiri, yaitu pihak-pihak dengan siapa organisasi ini berhubungan.Kesetiaan, kepercayaan dan dukungan yang diberikan kepada organisasi oleh kelompokkelompok seperti para petugas dan masyarakat umum..

\section{d. Faktor-faktor Yang Mempengaruhi Efektivitas}

Ada empat faktor yang mempengaruhi efektivitas kerja, seperti yang dikemukakan oleh Richard M. Steers dalam bukunya yang berjudul Efektivitas Organisasi, yaitu:

1) Karakteristik Organisasi

Karakteristik organisasi terdiri dari struktur dan teknologi organisasi yang dapat mempengaruhi segi-segi tertentu dari efektivitas dengan berbagai cara. Yang dimaksud struktur adalah hubungan yang relatif tepat sifatnya, seperti dijumpai dalam organisasi, sehubungan dengan susunan sumber daya manusia, struktur meliputi bagaimana cara organisasi menyusun orangorangnya dalam menyelesaikan pekerjaan, sedangkan yang dimaksud teknologi adalah mekanisme suatu organisasi untuk mengubah masukan mentah menjadi keluaran (output).

2) Karakteristik Lingkungan

$$
\text { Aspek lingkungan luar dan }
$$
lingkungan dalam juga telah dinyatakan mempunyai pengaruh terhadap efektivitas kerja.Kedua aspek tersebut sedikit berbeda, namun saling berhubungan.Lingkungan luar yaitu semua kekuatan yang timbul di luar batas-batas organisasi dan mempengaruhi keputusan serta tindakan di dalam organisasi.Pengaruh faktor semacam ini terhadap dinamika organisasi pada umumnya dianggap meliputi derajat kestabilan yang relatif dari lingkungan, derajat kompleksitas lingkungan dan derajat ketidak pastian lingkungan.Sedangkan lingkungan dalam yang pada umumnya disebut iklim organisasi, meliputi macam-macam atribut lingkungan kerja yang mempunyai hubungan dengan segi-segi tertentu dari efektivitas, khususnya atribut-atribut yang diukur pada tingkat individual.Keberhasilan hubungan organisasi dengan lingkungan tampaknya amat tergantung pada tingkat variabel kunci yaitu tingkat keterdugaan keadaan lingkungan, ketepatan persepsi atas keadaan lingkungan dan tingkat rasionalisme organisasi.Ketiga faktor ini mempengaruhi ketepatan tanggapan organisasi terhadap perubahan lingkungan.

3) Karakteristik Pekerja

Pada kenyataannya para anggota organisasi merupakan faktor pengaruh yang paling penting karena perilaku merekalah yang dalam jangka panjang akan memperlancar atau merintangi tercapainya tujuan organisasi. Pekerja merupakan sumber daya yang langsung berhubungan dengan pengelolaan semua sumber daya yang ada di dalam organisasi, oleh sebab itu perilaku pekerja sangat berpengaruh terhadap pencapaian tujuan organisasi. Pekerja merupakan modal utama di dalam organisasi yang akan berpengaruh besar terhadap efektivitas, karena walaupun teknologi yang digunakan merupakan teknologi yang canggih dan didukung oleh adanya struktur yang baik, namun tanpa adanya pekerja maka semua itu tidak ada gunanya.

4) Kebijaksanaan dan Praktek Manajemen

Secara umum, para pemimpin memainkan peranan sentral dalam keberhasilan suatu organisasi melalui perencanaan, koordinasi dan memperlancar kegiatan yang ditunjukan kearah sasaran.Kewajiban mereka para pemimpin untuk menjamin bahwa struktur organisasi konsisten dengan dan menguntungkan untuk teknologi dan lingkungan yang ada.Sudah menjadi tanggung jawab dari para pemimpin untuk menetapkan suatu sistem imbalan yang pantas sehingga para pekerja dapat memuaskan kebutuhan dan tujuan pribadinya sambil mengejar tujuan dan sasaran organisasi.Peranan pemimpin ini mungkin merupakan fungsi yang paling penting. Dengan makin rumitnya proses teknologi dan makin rumit dan kejamnya keadaan lingkungan, peranan manajemen dalam mengkoordinasi orang dan 
proses demi keberhasilan organisasi tidak hanya bertambah sulit, tapi juga menjadi semakin penting artinya.

\section{e. Pengelolaan Dana Bantuan Operasional Sekolah}

\section{1) Deskripsi Pengelolaan Dana BOS}

Pengelolaan adalah manajemen.Manajemen diartikan sebagai perencanaan, pengorganisasian, pelaksanaan dan pengawasan. Manajemen pada dasarnya merupakan suatu proses penggunaan sumber daya secara efektif untuk mencapai sasaran atau tujuan tertentu.Istilah biasa dikenal dalam ilmu ekonomi yang memfokuskan pada profit (keuntungan dan komoditas komersial).Manajemen dalam arti luas, menunjuk pada rangkaian kegiatan, dari perencanaan akan dilaksanakannya kegiatan sampai penilainnya. Manajemen dalam arti sempit, terbatas pada inti kegiatan nyata, mengatur atau mengelola kelancaran kegiatannya, mengetur kecekatan personi yang melaksanakan, pengaturan sarana pendukung, pengaturan dana, dan lain-lain, tetapi masih terkait dengan kegiatan nyata yang sedang belangsung.

Sesuai dengan Permendikbud No. 26 Tahun 2017 tentang Petunjuk teknis Pengelolaan Dana Bantuan Operasional Sekolah (BOS). BOS dikelola oleh SD/SDLB/SMP/SMPLB, SMA/SMALB/ SMK, dan SLB dengan menerapkan Manajemen Berbasis Sekolah (MBS), yang memberikan kebebasan dalam perencanaan, pengelolaan, dan pengawasan program yang disesuaikan dengan kondisi dan kebutuhan sekolah. Penggunaan ROS hanya untuk kepentingan peningkatan 1 i 30 a pendidikan dan tidak ada intervensi atau pemotongan dari pihak manapun.Pengelolaan BOS mengikutsertakan Dewan Guru dan Komite Sekolah. Pengelolaan BOS dengan menggunakan MBS wajib melaksanakan ketentuan sebagai berikut:

1. Mengelola dana secara profesional dengan menerapkan prinsip efisien, efektif, akuntabel, dan transparan;

2. Melakukan evaluasi setiap tahun; dan

3. Menyusun Rencana Kerja Jangka Menengah (RKJM), Rencana Kerja Tahunan (RKT), dan Rencana Kegiatan dan Anggaran Sekolah (RKAS), dengan ketentuan:

a. RKJM disusun setiap 4 (empat) tahun;

b. RKJM, RKT, dan RKAS disusun berdasarkan hasil evaluasi diri sekolah;

c. RKAS memuat penerimaan dan perencanaan penggunaan BOS; dan

d. RKJM, RKT, dan RKAS harus disetujui dalam rapat Dewan Guru setelah memperhatikan pertimbangan Komite Sekolah dan disahkan oleh dinas pendidikan provinsi/kabupaten/ kota sesuai dengan kewenangannya.

\section{2) Mekanisme Pengelolaan}

a. Tim PKPS-BBM mengumpulkan data jumlah siswa tiap sekolah melalui tim PKPSBBMpropinsi dan kabupaten / kota, kemudian menetapkan alokasi dan BOS tiap propinsi.

b. Atas dasar jumlah siswa di sekolah, tim PKPSBBM pusat membuat dana BOS tiap propinsi dituangkan dalam DIPA propinsi.

c. Tim PKPS-BBM kabupaten dan kota diharapkan melakukan verifikasi ulang data jumlah siswa sekolah.

d. Tim PKPS-BBM kabupaten /kota, menetukan sekolah yang bersedia menerima dana BOS melauli surat keputusan (SK) yang ditanda tangani oleh kepala Dinas pendidikan kabupaten/ kota, kepala Kandepag kabupaten / kota dan dewan pendidikan dengan dilampiri daftar nama sekolah dan besar dana bantuan ysng diterima sekolah bersedia menerima BOS harus menanda tangani surat perjanjian pemberian bantuan.

e. Tim PKPS-BBM kabpaten / kota mengirimkan daftar sekolah ke tim PKPS-BBM propinsi, tebusan ke Pos/ank dan sekolah penerima BOS.

\section{3) Mekanisme Pencairana Dana BOS}

a. Pencairan dana BOS dilakukan langsung di KPPN Kab/Kota dengan mengikuti mekanisme pencairan DIPA, yaitu dengan mengacu pada peraturan Dirjen perbendaharaan Nomor PER/066/PB/2005.

b. Jika sekolah ingin menggunakan dana BOS untuk kegiatan diluar belanja barang non operasional lainnya sebagaimana yang diatur dalam petunjuk pelaksanaan BOS, maka dipersilahkan dengan melakukan revisi DIPA terlebih dahulu sesuai dengan kebutuhan yang telah direncanakan dalam Rencana Anggaran dan kegiatan sekolah (RAKS) /RAPBM Revisi DIPA BOS dapat diproses melalui Kanwil Direktorat Jenderal perbendaharaan, termasuk revisi ke belanja modal.

c. Pengambilan dana BOS oleh bendahara pengelola BOS, dilakukan secara bertahap sesuai kebutuhan dengan terlebih dahulu mengajukan permohonan pencairan dana BOS dari rekening sekolah kepada bendahara pengeluaran yang diketahui oleh kepala kepala sekolah dan komite sekolah.

d. Jika jumlah dana BOS yang dilokasikan pada DIPA sekolah negeri lebih besar dari jumlah 
yang seharusnya, misalanya akibat kesalahan,/perubahan data jumlah siswa, maka harus segera mengembalikan kelebihan dana BOS tersebut ke Kasa Negara.

e. Jika sampai akhir tahun anggaran dana BOS masih tersisa direkening sekolah, maka sisa dana tersebut di setor ke Kas Negara.

4) Mekanisme Pengambilan Dana BOS

a. Tim PKPS-BBM propinsi menyerahkan data rekening sekolah penerima BOS dan besar dana yang harus disalurkan kepada kantor pos /bank pemerintah yang ditunjuk sebagai penyalur dana.

b. Selanjutnya kantor pos /bank yang ditunjuk mentransfer dan sekaligus setiap rekening sekolah, dan masuk kedalam pos penerimaan di dalam RAPBS.

c. Pengambilan dana BOS dilakukan oleh kepala sekolah dengan diketahui oleh ketua komite sekolah dan dapat dilakukan sewaktu-waktu sesuai kebutuhan dengan menyisakan saldo minimum sesuai peraturan yang berlaku. Saldo minimum ini bukan termasuk pemotongan. Pengambilan dana tidak seharusnya melalui sejenis rekomendasi/ persetujuan manejer atau tum PKPS-BBM kabupaten/ kota.

d. Dana Bos harus diterima secara utuh sesuai dengan SK alokasi yang dibuat oleh PKPSBBM kabupaten /kota dan tidak diperkenankan melakukan pemotongan atau pungutan biaya apapun dengan alasan apapun oleh pihak manapun.

e. Penyaluran dana BOS secara bertahap (dua atau tiga bulan) bukan berarti dana harus dihabiskan dalam periode tersebut. Besar penggunaan dana tersebut dalam setiap bulan disesuaikan dengan kebutuhan sekolah sebagaimana tertuang dalam RAPBS. Bilamana terdapat sisa dana tersebut tetap milik kas sekolah (tidak disetor di kas Negara).

\section{5) Pemanfaatan Dana Bantuan Operasional Sekolah (BOS)}

Program BOS dalam pemanfaatannya adalah untuk pemerataan dan perluasan akses, program BOS juga merupakan program untuk peningkatan mutu, relevansi dan daya saing serta untuk tata kelola, akuntabilitas dan pencitraan publik. Melalui program ini yang terkait dengan pendidikan dasar 9 tahun, setiap pengelola program pendidikan harus memperhatikan hal-hal berikut:

a) BOS harus menjadi sarana penting untuk meningkatkan akses dan mutu pendidikan dasar 9 tahun; b) tidak adanya peserta didik miskin yang putus sekolah;

c) lulusan SD harus diupayakan keberlangsungan pendidikannya ke SMP;

d) kepala sekolah mengajak peserta didik SD yang akan lulus dan berpotensi tidak melanjutkan sekolah ditampung di SMP sementara, apabila terdapat peserta didik SMP yang akan putus sekolah agar diajak kembali ke bangku sekolah;

e) kepala sekolah bertanggung jawab mengelola dana BOS secara transparan dan akutabel;

f) BOS bukan penghalang bagi peserta didik, orang tua, atau walinya dalam pemberian sumbangan sukarela yang tidak mengikat kepada sekolah.

Dalam pertanggung jawaban dan BOS sepenuhnya menjadi tanggung jawab lembaga yang kegiatannya mencatat penerimaan, dan pengeluaran uang serta pelaporan keuangan, sehingga memudahkan proses pengawasan atas penggunaan dana.

a) Rencana anggaran pendapatan dan belanja sekolah

1. Penggunaan dana BOS yang telah disepakati oleh kepala sekolah/dewan guru/ komite sekolah madrasah atau yayasan dituangkan dalam RAPBS dan ditanda tangani oleh kepala sekolah, ketua komite dan ketua yayasan.

2. PABS (format BOS-K1)

3. Rincian penggunaan dan perjenis anggaran (format BOS-K2)

b) Pengelolaan dan BOS berpedoman pada:

1. Ketentuan pembayaran atas APBN

2. Ketentuan pengadaan barang / jasa instansi pemerintah.

3. Ketentuan perpajakan

4. Ketentuan pembukuan keuangan Negara

c) Pembukuan

1. Pengelolaan dana BOS diwajibkan membuat pembukuan kas umum(format ke-3), buku pembantu kas tunai (format-BOS k4), buku pembantu bank (format BOS k-5) buku pembantu pajak (format BOS k-6) dan buku pembantu lainnya sesuai dengan kebutuhan.

2. Semua transaksi penerimaan dan pengeluaran dicatat dalam pengeluaran buku kas umumdan buku pembantu yang relevan sesuai dengan urutan tanggal kejadiannya.

3. Setiap akhir bulan buku kas umum dan buku pembantu ditutup oleh bendahara dan ketahui oleh kepala sekolah.

4. Uang tunai yang ada dikas tunai tidak lebih dari Rp.5 juta. 
d) Bukti Pengeluaran

1. Setiap transaksi keuangan harus didukung dengan bukti kuitansi yang sah

2. Bukti pengeluaran dalam jumlah tertentu harus dibubuhi materi yang cukup sesuai dengan ketentuan bea materai

3. Uraian pembayaran dalam kuitansi harus jelas dan terinci

4. Uraian jenis barang /jasa yang dibayar dapat dipisahkan dalam bentuk faktur sebagai lampiran kuitansi.

5. Setiap bukti pembayaran harus disetujui oleh kepala sekolah dan lunas dibayar oleh bendahara.

1) Pelaporan

Dalam aturan Kementrian Agama menjelaskan bahwa laporan merupakan pertanggung jawaban atas pelaksanaan kegiatan yang dibiayai dana BOS. Untuk itu laporan pertanggung jawaban harus memenuhi unsur-unsur sebagai berikut :

1. Setiap kegiatan wajib dibuatkan laporan hasil pelaksanaan kegiatannya

2. Seluruh arsip data keuangan, baik yang berupa laporan keuangan maupun dokumen pendukungnya disimpan dan ditata dengan rapi dalam urutan nomor dan tanggal kejadiannya, serta disimpan disuatu tempat yang aman dan mudah ditemukan disetiap saat.

3. Laporan penggunaan dana BOS dari penanggung jawab/ pengelolaan dana BOS ditingkat sekolah kepada tim PKPS-BBM Kab/Kota cukup format BOS-K2, sedangkan format BOS K-3, format BOS K-4, format BOS K-5 dan format BOS-K6 beserta dokumen pendukungnya diarsipkan disekolah .

4. Waktu pelaporan pertanggung jawaban keuangan tersebut disampaikan setiap triwulan, semester dan tahunan.

\section{Metode Penelitian}

Jenis penelitian ini menggunakan jenis deskriptif kualitatif, yang menggambarkan sekaligus mengkaji kondisi riil objek penelitian berdasarkan data-data autentik yang dikumpulkan untuk mengkaji masalah bagaimana Efektivitas Pengelolaan Dana Bantuan Operasional Sekolah (BOS) Dalam Meningkatkan Sarana dan Prasarana Pendidikan di SDN 44 Mande Kota Bima, maka haruslah dikaji berdasarkan kondisi riil dilapangan, sehingga dapat diperoleh data yang bersifat deskriptif yang berupa kata-kata tertulis atau lisan.

Oleh karena itu hasil penelitian akan berisi kutipan-kutipan data untuk memberikan gambaran penyajian laporan tersebut "Data berasal dari observasi, wawancara (interview), dokumentasi dan gabungan /triangulasi”.

Lokasi penelitian ini dilaksanakan di SDN 44 Mande Kota Bima, Kelurahan Mande, Kecamatan Mpunda, Kota Bima.Pemilihan lokasi ini didasari pertimbangan sekolah ini cukup representatif dan memiliki relevansi spesifik bagi kepentingan penelitian. Waktu penelitian dilakukan selama 30 hari.

Dalam penelitian kualitatif digunakan istilah-istilah informan penelitian atau sumber data dari seseorang atau beberapa orang yang di anggap representative bagi kepentingan data penelitian.Dalam penelitian ini tahapan awal yang dilakukan adalah menentukan informan kunci yaitu kepala sekolah. Dari informan diperoleh informasi tambahan lain untuk melengkapi data antara lain guru,bendahara atau pengelola dana BOS, guru/pegawai honorer sampai komite sekola 59 a staf pada Dinas Pendidikan dan Kebudayaal. ...... Bima yang mengetahui informasi tentang data tersebut.

Sumber data mencakup keseluruhan aspek pada populasi yang ada dan berhubungan dengan objek penelitian. Oleh karena itu sumber data dalam penelitian ini terdiri dari dua yaitu:

a. Data primer atau data utama diperoleh dari hasil wawancara dengan para informan penelitian. Informan dalam penelitian ini terdiri dari informan kunci yang meliputi kepala sekolah, bendahara atau panitia pengelola dana BOS dan informan tambahan seperti guru/pegawai honorer sampai komite sekolah dan staf pada Dinas Pendidikan dan Kebudayaan Kota Bima yang menerima laporan penggunaan dana BOS setiap triwulannya.

b. Data sekunder atau data pendukung diperoleh dari hasil observasi lapangan, bahan dokumen, dan referensi lain yang sesuai dengan judul penelitian.

Adapun teknik pengumpulan data yang digunakan untuk mengumpulkan data ialah sebagai berikut:

a. Observasi (observation) dimana peneliti melakukan pengamatan terhadap beberapa objek yang akan diteliti yaitu di SDN 44 Mande Kota Bima yang terdiri dari kepala sekolah dan seluruh perangkat sekolah serta orang tua atau masyaraka tsekitar. Hasil pengamatan ini diakumulasi sebagai data lengkap kemudian direduksikan dalam skripsi.

b. Wawancara (interview) yaitu mengadakan wawancara berupa pertanyaan-pertanyaan yang memerlukan jawaban berupa informasi untuk 
mengetahui secara mendalam tentang berbagai informasi yang sesuai dengan permasalahan yang diteliti agar dokumentasi lebih terarah.

c. Dokumentasi, disamping wawancara dan observasi penelitian ini juga menggunakan teknik dokumentasi sebagai pelengkap data yang sesuai permasalahan penelitian. Seperti buku dokumen penggeluaran dana BOS dan buku panduan RAPBS.

Tehnik analisis data adalah proses mencari dan menyusun secara sistematis data yang diperoleh dari hasil wawancara, observasi dan dokumentasi dengan cara mengorganisasikan sebuah data kedalam kategori, menjabarkan, melakukan sintesa, memilih mana yang penting dalam membuat kesimpulan agar mempermudah diri sendiri maupun orang lain. Sehubungan dengan itu Miles dan Huberman dalam Sugiono menjelaskan bahwa dalam tehnik analisis data maka data dapat dianalisis sebagai berikut:

1) Reduksi data

2) Display data (penyajian)

3) Vertifikasi data

Pengolahan data merupakan proses akhir dari penelitian yang dilakukan, sehingga pengolahan data dilakukan setelah peneliti memperoleh data lapangan.Dalam penelitian ini peneliti menggunakan penelitian kualitatif, maka analisis datanya dilakukan dengan cara reduksi data, display data dan verifikasi data:

1. Reduksi data yaitu semua data lapangan akan dianalisis sekaligus dirangkum dipilih hal-hal yang pokok dan difokuskan pada hala-hal yang dirangkum.

2. Display data yaitu tehnik yang dilakukan olehpeneliti agar data yang diperoleh banyaknya jumlah dapat dikuasai dengan dipilih secara fisik membuat display merupakan dari analisis pengambilan data.

3. Verifikasi data yakni tehnik analisa data yang dilakukan dalam mencari makna data dengan mencoba mengumpulkannya, kemudian diolah sedemikian rupa sehingga data-data yang pada awalnya belum lengkap akan tertutupi.

Pengolahan data merupakan proses akhir dari penelitian yang dilakukan. Prosedur analisa data idealnya tidak kaku dan senantiasa dikembangkan sesuai kebutuhan dan sasaran penelitian analisis data.

Dalam penelitian kualitatif ditetapkan keabsahan data untuk menghindari data yang tidak valid sebagai usaha untuk meningkatkan derajat kepercayaan data dan untuk menyanggah balik apa yang dituduhkan penelitian kualitatif yang menyatakan tidak ilmiah. Pengujian keabsahan data dalam penelitian menggunakan triangulasi, dalam tehnik ini triangulasi pengujian keabsahan data dengan memanfaatkan suatu hal lain yang diluar data yang telah ada kemudian, diadakan pengujian lagi untuk mendapatkan data yang lebih valid.

Dalam pengujian keabsahan data, dilakukan melalui perpanjangan pengamatan, meningkatkan ketekunan, dan triangulasi sumber data dan tehnik.Perpanjangan pengamatan, dalam hal ini peneliti kembali terjun kelapangan untuk melakukan pengamatan ulang dengan sumber data yang pernah ditemui maupun yang baru, dalam hal ini kepala sekolah, guru, maupun siswa. Peneliti mengecek kembali apakah data yang telah diberikan selama ini merupakan data yang benar atau salah.Meningkatkan ketekunan, berarti melakukan pengamatan lebih cepat dan berkesinambungan.Dengan meningkatkan ketekunan ini maka peneliti dapat mengecek kembali apakah data yang pernah diberikan dapat teruji keabsahannya.

Triangulasi dalam pengujian kredibilitas diartikan "sebagai pengecekan berbagai sumber dengan berbagai cara dan berbagai waktu" triangulasi dalam hal ini terbagi dua yaitu:

1. Triangulasi sumber data adalah pengujian kredibilitas data yang dilakukan dengan cara mengecek data yang telah diperoleh melalui beberapa sumber.

2. Triangulasi tehnik adalah pengujian kredibilitas data yang dilakukan dengan cara mengecek data kepada sumber yang dengan tehnik yang berbeda.

Member check adalah pengujian kredibilitas data melalui proses pengecekan data kepada pemberi data dengan tujuan untuk mengetahui sejauh mana data yang diperoleh sesuai dengan apa yang diberikan sebelumnya. Dalam member cek peneliti menemui kembali subjek peneliti untuk mengecek kembali data hasil wawancara yang telah dilakukan sehingga meningkatkan kredibilitas data..

\section{PEMBAHASAN}

\section{a. Kepatuhan Implementasi dan Kesesuaian Pelaksanaan Pengelolaan Dana Bantuan Operasional Sekolah (BOS) dalam Meningkatkan Sarana dan Prasarana di SDN 44 Mande Kota Bima}

Pengelolaan dana bantuan operasional sekolah yang dilaksanakan oleh SDN 44 Mande Kota Bima, berdasarkan hasil temuan yang diperoleh menunjukkan bahwa sekolah ini telah melaksanakan program bantuan operasional sekolah 
sesuai dengan ketentuan yang berlaku yaitu berdasarkan Permendikbud No. 26 Tahun 2017 tentang Petunjuk Teknis Bantuan Operasional Sekolah (BOS) yang telah dimuat dalam petunjuk teknis pengelolaan dan pertanggung jawaban dana BOS. Para pengelola telah menguasai dengan baik tahapan-tahapan pengelolaan dana tersebut baik dari proses perencanaan sampai dengan ke proses evaluasi dan pertanggungjawaban.

Tujuan program bantuan operasinal sekolah adalah untuk meningkatkan kualitas pendidikan dalam upaya menciptakan kualitas sumber daya manusia yang unggul.Untuk meningkatkan sumber daya manusia Indonesia yang unggul, maka diperlukan keikutsertaan tiap warga negara Indonesia secara aktif dalam pendidikan.

Pelaksanaan program BOS tidak serta merta dilaksanakan berdasarkan keinginan dan kebutuhan sekolah. Untuk itu, pemerintah menerbitkan buku petunjuk teknis penggunaan dan pertanggungjawaban keuangan dana BOS dalam setiap tahunnya. Dalam buku petunjuk tersebut sudah jelas tertulis aturan-aturan pelaksanaan program BOS mulai dari dasar penyeleng 90 I program BOS, tujuan BOS, sasaran, pelaksaıran program, prosedur pelaksanaan BOS, komponen yang dapat dibiayai dana BOS, larangan penggunaannya, sampai pada monitoring dan laporan pertanggungjawaban sekolah, termasuk juga format-format kegiatan BOS serta pelayanan dan penanganan pengaduan masyarakat terkait pelaksanaan program BOS di sekolah tersebut.

Penggunaan dana BOS di sekolah harus didasarkan pada kesepakatan dan keputusan bersama antara Tim Manajemen BOS Sekolah, Dewan Guru dan Komite Sekolah. Dana BOS harus didaftar sebagai salah satu sumber penerimaan dalam RKAS/RAPBS, di samping dana yang diperoleh dari Pemda atau sumber lain yang sah.

Prinsip-prinsip yang harus dimiliki oleh para pengelola didalam menggunakan dana BOS sehingga penggunaan dana dapat maksimal dan efektif, yaitu seperti halnya:

a. Tim pengelola harus menggunakan prinsip keterbukaan dan ekonomis dalam menentukan barang/jasa dan tempat pembeliannya,

b. Tim pengelola harus memperhatikan kualitas barang/jasa, serta ketersediaan, dan kewajaran harga,

c. Tim pengelola harus selalu membandingkan harga penawaran dari penyedia barang/jasa dengan harga pasar dan melakukan penawaran harga kepada penyedia barang, apabila harga penawaran lebih tinggi dari harga pasar, maka pengelola harus mampu melalkukan penawaran,

d. Terkait dengan biaya untuk perawatan ringan/pemeliharaan bangunan sekolah, Tim pengelola harus menerapkan prinsip-prinsip berikut:

1) Membuat rencana kerja,

2) Memilih satu atau lebih pekerja untuk melaksanakan pekerjaan tersebut dengan standar upah yang berlaku di masyarakat.

3) Membuat laporan penggunaan dana (pembelian barang dan pembayaran upah) untuk kegiatan perawatan ringan/ pemeliharaan sekolah (Permendikbud No 01. 2018).

Dalam pelaksanaan dana BOS, ini dibagi menjadi 8 standar penggunaan atau aliran dana BOS yaitu: Pengembangan Kompetensi Kelulusan, Pengembangan Standar Isi, Pengembangan Standar Proses, Pengembangan Pendidik dan Tenaga Kependidikan, Pengembangan Sarana dan Prasarana Sekolah, Pengembangan Standar Pengelolaan, Pengembangan Standar Pembiayaan, Pengembangan dan Implementasi Sistem Penilaian.

\section{b. Faktor Pendukung Pengelolaan Dana Bantuan Oeprasional Sekolah (BOS) SDN 44 Mande Kota Bima}

Faktor-faktor pendukung keberhasilan dari pengelolaan danabantuan operasional sekolah yaitu segala sesuatu yang memberikan dukungan baik berbentuk kebijakan, benrbentuk kerja sama yang baik, berbentuk dukungan material, berbentuk sumbangan pemikiran, dukungan berbentuk tenaga, dll. Keberhasilan suatu program tidak terlepas dari dukungan dari sagala sektor sehingga pelaksanaannya akan lebih muda menuju keberhasilan yang diinginkan. Sehingga semakin banyak dukungan positif yang didapatkan dalam pelaksanaan program maka semakin besar peluang untuk mencapai keberhasilan.

Dalam pengelolaan dana bantuan oeparsional sekolah juga sangat dipengaruhi oleh faktor pendukung untuk mewujudkan tujuan yang direncanakan. Adapun faktor-faktor yang mendukung yaitu:

1) Dukungan pemerintah dangan memberikan sosialisasi pengelolaan dana BOS dan penmberian petunjuk teknis pengelolaan dana bantuan operasional sekolah,

2) Bentuk kerja sama yang terjalin dengan baik oleh para pengelola dengan seluruh guru dan komeite sekolah,

3) Motivasi dan tekat yang kuta dari seluruh pihak sekolah untuk memajukan kualitas pendidikan,

4) Kinerja kepala sekolah yang baik. 


\section{c. Faktor Penghambat Pengelolaan Dana Bantuan Operasional Sekolah (BOS) SDN 44 Mande Kota Bima}

Dalam pengelolaan dana bantuan operasional sekolah di SDN 44 Mande Kota Bima juga mengalami hal-hal yang sifatnya dapat menghambat keberhasilan pelaksanaan program bantuan operasional sekolah tersebut seperti yang telah disebutkan diatas, bahwa salah satu yang dapat membuat suatu kebijakan tidak dapat berjalan dengan baik yaitu dikarenakan kebijakan tersebut dalam pelaksanaannya kurang memperhatikan masalah teknis, hal ini dapat dibuktikan dimana dalam peraturan yang dimuat dalam petunjuk teknis pengelolaan dana BOS, Sekolah tidak diberikan kebebasan untuk menggunakan dana bantuan operasional tersebut sesuai dengan kebutuhan sekolah, seperti misalnya sekolah tidak diperbolahkan untuk melakukan perbaikan berat dan pembuatan gedung baru menggunakan dana BOS. Hal ini menjadi salah satu faktor penghambat untuk mecapai tujuan yang direncakan yaitu meningkatkan kualitas pendidikan.

Selain daripada itu dalam pengelolaan dana bantuan operasional sekolah juga mengalami Adanya kekurangan akan tersedianya sumbersumber pembantu (waktu, uang dan sumber daya manusia), untuk permasalahan waktu yang menjadi masalah yaitu ketika pencairan dana bantuan operasional sekolah sering mengalami keterlambatan sehingga akan berdampak terhadap program-program sekolah yang tidak dapat berjalan sesuai dengan apa yang telah direncanakan, kemudian permasalhan yang terjadi terhadap uang/anggaran yaitu dimana anggaran bantuan operasional sekolah yang diterimah oleh sekolah tertentu khusunya sekolah terbelakang tidak sebanding dengan kebutuhan sekolah tersebut sehingga pembangunan yang terjadi tidak efektif dan sifatnya tidak menyeluruh serta ini berdampak terhadap keberhasilan yang tidak maksimal sesuai dengan tujuan yang direncanakan.

Penentuan anggaran Program bantuan operasional (BOS) yang diperoleh sekolah penerimah dana BOS yaitu ditentukan dari banyak atau sedikitnya jumlah siswa, semakin banyak siswa suatu sekolah maka anggaran yang diperoleh semakin besar dan sebaliknya semakin sedikit siswa suatu sekolah maka semakin kecil anggaran dana BOS yang diterimah. Dalam hal ini sesuai dengan teori diatas maka dapat dikatan Kebijakan yang ditetapkan itu mengandung banyak lubang.

\section{Simpulan}

Berdasarkan hasil penelitian dan pembahasan maka penelitian ini dapat disimpulkan sebagai berikut:

a. Berdasarkan Teori Ripley dan Franklin terkait kepatuhan implementasi serta kesesuaian pelaksanaan. Bahwa, SDN 44 Mande Kota Bima dalam pengelolaan dana bantuan operasional sekolah (BOS) telah berjalan sesuai dengan petunjuk teknis pengelolaan dana bantuan operasional sekolah (JUKNIS BOS). Adapun proses pelaksanaan yang dilakukan yaitu:

1) Membuat rencana anggaran belanja sekolah (RAPBS),

2) Diadakan rapat yang dihadiri oleh kepla sekolah, pihak pengelola dana BOS, Komite Sekolah, guna untuk membahas tentang pemanfaatan dana BOS,

3) Dana dialokasikan untuk program-program seperti:

a) pengembangan perpustakaan,

b) kegiatan dalam rangka penerimaan siswa baru,

c) kegiatan pembelajaran dan ekstrakurikuler siswa,

d) kegiatan ulangan dan ujian,

e) langganan daya dan jasa,

f) perawatan sekolah/rehab ringan dan senitasi sekolah,

g) pembayaran honorium bulanan,

h) pengembangan profesi guru dan tenaga kependidikan,

i) biaya pengelolaan sekolah,

j) pembelian dan perawatan perangkat komputer, dan

k) biaya lain-lain.

4) Membuat rincian penggunaan dana bantuan operasional sekolah dalam bentuk laporan pertanggung jawaban yang akan di rapatkan dan diserahkan ke Dinas Pendidikan dan Kebudayaan, dan

5) Melakukan evaluasi terhadap program yang telah dilaksanakan.

b. Faktor pendukung dan penghambat dalam pengelolaan dana bantuan operasional sekolah (BOS).

a. Faktor Pendukung

Adapun faktor pendukung dalam pengelolaan dana bantuan operasional sekolah (BOS) adalah sebagai berikut:

1) Dukungan Pemerintah dengan memberikan petunjuk teknis pengelolaan dana BOS dan sosialisasi tentang tatacara pengelolaan dana 
bantuan operasional sekolah dari Dinas Pendidikan,

2) Terjalinnya bentuk kerja sama yang baik dari pihak pengelola dana BOS, Komite Sekolah dan para Guru, Pemerintah (Dinas Pendidikan dan Kebudayaan Kota bima),

3) Motivasi yang tinggi dan kinerja yang maksimal,

4) Dukungan dari para guru baik dengan sumbangan pemikiran maupun dengan dukungan tenaga.

b. Faktor penghambat

Adapun faktor penghambat dalam pengelolaan dana bantuan operasional sekolah (BOS) yaitu:

1) Waktu pencairan dana sering mengalami keterlambatan,

2) Anggaran yang diperoleh tidak sebanding dengan kebutuhan sekolah

3) Sekolah dibatasi dalam melakukan perbaikan berat sehingga sekolah masih mengalami kekurangan ruangan, dan

4) Dana bantuan operasional sekolah belum mampu membiayai seluruh program sekolah secara merata/menyeluruh.

\section{Saran}

Sesuai dengan simpulan diatas maka peneliti menawarkan beberapa saran yaitu sebagai berikut:

a. Kepada Dinas Pendidikan dan Kebudayaan Kota Bima disarangkan agar lebih aktif untuk merespon permasalahan-permasalahan yang dihadapi oleh pihak pengeloladana bantuan operasional sekolah (BOS).

b. Kepada Kepala Sekolah SDN 44 Mande Kota Bima selaku pimpinan dan penaggung jawab dari anggaran dana bantuan operasional sekolah (BOS) disarankan untuk tetap transparansi serta bijak didalam memanfaatkan anggaran bantuan operasional sekolah.

c. Kepada Komite Sekolah baik guru, orang tua siswa, dan tokoh masyarakat disarankan untuk keterlibatannya dalam mengawasi pengelolaan dana bantuan operasional sekolah tersebut. Serta diharapkan dapat memberikan sumbangan pemikiran dan solusi-solusi penyelesaian masalah.

d. Kepada semua guru SDN 44 Mande Kota Bima baik yang berstatus PNS maupun Non PNS disarankan agar terus dapat meningkatkan kualitas pembelajaran dikelas serta berusaha memenuhi standar-standar kompetensi tenaga pendidik.

\section{Daftar Pustaka}

[1] Akdon, dkk. 2015. Manajemen Pembiayaan Pendidikan. Bandung: PT Remaja Rosdakarya.

[2] Bafadal, Ibrahim. 2012. Manajemen Peningkatan Mutu Sekolah Dasar Dari Sentralisasi Menuju Desentralisasi. Jakarta: PT Bumi Aksara.

[3] Fattah, Nanang. 2000. Ekonomi dan Pembiayaan Pendidikan, Bandung: Rosda Karya.

[4] Gunawan, Imam. 2015. Metode Penelitian Kualitatif Teori dan Praktik. Jakarta: PT Bumi Aksara.

[5] Hamiyah, Jauhar. 2015. Pengantar Manajemen Pendidikan Di Sekolah. Jakarta: Prestasi Pustakaraya.

[6] Matin. 2014. Manajemen Pembiayaan Pendidikan: Konsep dan Aplikasinya. Depok: PT Raja grafindo Persada.

[7] Mulyono. 2010. Konsep Pembiayaan Pendidikan. Yogyakarta: Ar-Ruzz Media.

[8] Ripley, Randall B. \& Franklin, Grace A. 1986.Policy Implementation and Bureaucracy. The Dorsey Press. Chicago, Illinois.

[9] Widjaya, A. W. 1987. Pengantar Bisnis "Manajemen dan Organisasi. Jakarta: Bina Aksara.

\section{Artikel/Modul/Diktat}

[1] Ahmad, Lokman Mohd. 2014. School Operational Funding to Support School Activities.Jurnal Universitas Negeri Malaysia. Diakses melalui http://ijere.iaescore.com/index.php/IJERE/ar ticle/view/4463. pada 27 Februari 2019 pukul 21.40 WITA

[2] Anggraini, Ristya Dwi. 2013. Transparansi, Partisipasi, dan Akuntabilitas PengelolaanAnggaran Dana BOS Dalam Program RKAS di SDN Pacarkeling VIII Surabaya. Jurnal. Universitas Airlangga.Diakses melalui http://journal.unair.ac.id/KMP@transparansi ,-partisipasi,-dan-akuntabilitas-pengelolaananggaran-dana-bos-dalam-program-rkas-disdn-pacarkeling-viii-surabaya-article-9273media-138-category-8.html pada 27 Februari 2019 pukul 21.13 WITA

[3] Arifin. Barnawi.2012. Etika dan Profesi Kependidikan. Jogjakarta: Ar-ruzz Media. 
[4] Artana, Made, dkk. 2014.Efektivitas Pengelolaan Dana Bantuan Operasional Sekolah(BOS) Pada Sekolah Dasar di Kecamatan Sukasada. Jurnal UniversitasPendidikan Ganesha. Diakses melalui

https://ejournal.undiksha.ac.id/index.php/JJP E/article/view/4118.pada 27 Februari 2019 pukul 21.20 WITA

[5] Atmaja, R.M.T.E., Harun, C.Z.H., \& Ibrahim,S. 2016. Analisis Penetapan Standar BiayaPendidikan Pada SMA Negeri 2 Kuala Kabupaten Nagan Raya. Jurnal AdministrasiPendidikan Pascasarjana Universitas Syiah Kuala (4)1 : 119 - 128. Diakses melalui https://www.neliti.com/id/publications/7254 9/analisis-penetapan-standar-biayapendidikan-pada-sma-negeri-2-kualakabupaten-napada 27 Februari 2019 pukul 21.40 WITA

[6] Bachri, Bachtiar. 2010. Meyakinkan Validitas Data Melalui Triangulasi padaPenelitian Kualitatif. Jurnal Teknologi Pendidikan. 10 (1): 46-62. Diakses melalui http://yusuf.staff.ub.ac.id/files/2012/11/mey akinkan-validitas-data-melalui-triangulasipada-penelitian-kualitatif.pdf pada 27 Februari 2019 pukul 21.40 WITA

[7] Baharudin, dkk. 2013. Akuntabilitas Pengelolaan Dana Bantuan Operasional Sekolah (BOS) di Kecamatan Minasatene Kabupaten Pangkep. Jurnal Universitas Hasanuddin.Diakses melalui http://pasca.unhas.ac.id/jurnal/files/042d6c7 36ed24b30de6f322e11b9cfa6.pdfpada 27 Februari 2019 pukul 21.40 WITA

[8] Baihaqi.2016. Manajemen Pembiayaan Pendidikan Pada SMK Negeri Di Kabupaten AcehBesar.Jurnal Pencerahan (6)1: 1- 9. Diakses melalui https://docplayer.info/30328608-

Manajemen-pembiayaan-pendidikan-padasmk-negeri-di-kabupaten-aceh-

besar.htmlpada 27 Februari 2019 pukul 21.58 WITA

[9] Fitri, Afrilliana. 2014. Pengelolaan Dana Bantuan Operasional Sekolah (BOS) SekolahDasar Negeri Kecamatan Mandiangin Koto Selayan Kota Bukittinggi..Jurnal Universitas Negeri Padang.Diakses melalui http://ejournal.unp.ac.id/index.php/bahana/ar ticle/view/3753 pada 27 Februari 2019 pukul 21.45 WITA

[10] Hasibuhan, Malayu. 2007. Manajemen dasar, Pengertian, dan Masalah.Jakarta: PT Bumi Aksara.Https:// andimpi.blogspot. com/2013/06/pembiayaan-pendidikan-diindonesia.html.Diakses pada 27 Februari 2019 pukul 21.23 WITA.

[11] Https://belajarpsikologi.com/pentingnyapendidikan-bagi-kehidupan/. Diakses Februari 2019 pukul 21.35 WITA.

[12] Https://cnnindonesia.com/nasional/2016052 1103521-20-132385/penyimpangan-danabos-terjadi-karena-pelanggaran-regulasi. Diakses 13 Maret 2019 pukul 09.45 WITA.

[13] Https://silabus.org/pengertian-pendidikan/. Diakses 27 Februari 2019 pukul 22.02 WITA.

[14] Ismaya. 2015. Pengelolaan Pendidikan. Bandung: PT Refika Aditama Jakarta:Bumi

[15] Aksara.

[16] Kaswandi. 2015. Evaluasi Pengelolaan Dana Bantuan Operasional Sekolah di SDN 027 Tarakan. Jurnal Universitas Sam Ratulangi. Diakses melalui http://ejournal.umm.ac.id/index.php/jmkpp/a rticle/view/2201 pada 27 Februari 2019 pukul 21.48 WITA

[17] Kiprono, Faith J. Dkk. 2015.An Assessment Of School Management Committees'Capacity In The Implementation Of Fpe Funds In Public Primary Schools: A Survey Of Eldoret East District, Kenya. Diakses melalui http://ir.mu.ac.ke:8080/xmlui/bitstream/hand le/123456789/1945/Joyce\%20et\%20al\%2C $\%$ 202014..pdf?sequence $=1 \&$ isAllowed $=\mathrm{y}$ pada 27 Februari 2019 pukul 21.35 WITA

[18] Peraturan Pemerintah Republik Indonesia Nomor 20 Tahun 2003 tentang SistemPendidikan Nasional. Diakses melalui https://kelembagaan.ristekdikti.go.id/wpcont ent/uploads/2016/08/UU_no_20_th_2003.pd fpada 27 Februari 2019 pukul 21.24 WITA

[19] Peraturan Pemerintah Nomor 17 Tahun 2010 tentang Pengelolaan dan Penyelengaraan Pendidikan.Diakses melalui https://kelembagaan.ristekdikti.go.id/wpcontent/uploads/2016/08/PP-66-Tahun2010.pdf pada 27 februari 2019 pukul 21.04 WITA

[20] Peraturan Menteri Pendidikan dan Kebudayaan Republik Indonesia Nomor 76 
Tahun 2012 tentang Petunjuk Teknis Pengunaan dan Pertanggungjawaban Keuangan dana Bantuan Operasional Sekolah Tahun Anggaran 2013.Diakses melalui

https://kelembagaan.ristekdikti.go.id/wpcontent/uploads/2016/11/bn1375-2012.pdf pada 27 februari 2019 pukul 21.10 WITA

[21] Peraturan Menteri Pendidikan dan Kebudayaan Republik Indonesia Nomor 26 Tahun 2017tentang Petunjuk Teknis Bantuan Operasional Sekolah. Diakses melalui

http://psmk.kemdikbud.go.id/konten/2560/p ermendikbud-nomor-26-tahun-2017petunjuk-teknis-bantuan-operasionalsekolah pada 16 agustus 2019 pukul 19.20 WITA

[22] Peraturan Pemerintah Nomor 19 Tahun 2005 tentang Standar Nasional Pendidikan.Diakses melalui https://kemenag.go.id/file/dokumen/PP1905. pdf pada 27 Februari 2019 pukul 20.44 WITA

[23] Permendiknas No. 24 Tahun 2007tentang Standar Sarana Dan Prasarana Untuk Sekolah Dasar/Madrasah Ibtidaiyah (SD/MI), Sekolah Menengah Pertama/Madrasah Tsanawiyah (SMP/MTs), Dan Sekolah Menengah Atas/Madrasah Aliyah (SMA/MA).Diakses melalui https://disdik.tebingtinggikota.go.id/peratura n-menteri/25-permendiknas-no-24-tahun2007 pada 27 februari 2019 pukul 19.55 WITA

[24] Suyatmini. Widyatmoko, Subkhi. 2017. Pengelolaan Dana Bantuan Operasional Sekolah (BOS) di SDN Kemasan I Surakarta. Jurnal Universitas Muhammadiyah Surakarta. Diakses melalui http://eprints.ums.ac.id/52171/ pada 27 februari 2019 pukul 19.56 WITA

[25] Undang-Undang Nomor 20 Tahun 2003 tentang sistem pendidikan nasional.Diakses melalui https://kelembagaan.ristekdikti.go.id/wpcontent/uploads/2016/08/

[26] UU_no_20_th_2003.pdf pada 27 februari 2019 pukul 19.59 WITA

[27] Waluyo, Kiky Bagus. 2012. Efektivitas Manajemen Dana Bantuan Operasional Sekolah (BOS) Dalam Meningkatkan Mutu Pendidikan (Studi Kasus Pengelolaan Dana BOS di SDN Pacarkeling 1 Surabaya).
Jurnal Universitas Airlangga. Diakses melalui http://repository.unair.ac.id/16347/ pada 27 februari 2019 pukul 20.20 WITA 